\title{
富山県舟橋村における人口減少克服に向けた子育て共助型モデルエリアのマネジメント
}

\section{A Study on the Management of a Model Area Considering Childcare Support and Mutual Assistance to Overcome Population Decline in Funahashi Village, Toyama Prefecture}

\author{
北村 優人* 金岡 省吾** 小松 亜紀子*** 市村 恒士* \\ Yuto KITAMURA Shogo KANAOKA Akiko KOMATSU Koji ICHIMURA
}

\begin{abstract}
In recent years, the community development by the childcare support and mutual assistance that contributes to regional revitalization policy is expected to overcome a declining population. Under such a background, we clarified the change of consciousness of users of a model area considering childcare support and mutual assistance in Funahashi Village, Toyama Prefecture. A questionnaire survey was distributed to the service users of the model area to identify (1) factors affecting the rating of the service (satisfaction with each service item), (2)overall rating of the service (overall satisfaction), and (3) changes in user's consciousness regarding "participation in childcare services", "mutual assistance", "emigration and settlement." After collecting questionnaire responses, covariance structure analysis was conducted to verify the relationship among valuables of these 3 questions. We found that the change of user's consciousness (3) was directly affected by satisfaction with "each service item" (1) and "overall satisfaction" (2). Considering these findings, we proposed appropriate directions for the future development of the community development by childcare support and mutual assistance and the direction of new business style reform in the landscaping industry.
\end{abstract}

Keywords: regional creation, child care support service, mutual assistance, change of user's consciousness, covariance structure analysis, key performance index

キーワード：地方創生，子育て支援サービス，共助，利用者の意識変化，共分散構造分析，重要業績評価指標

\section{1. はじめに}

今後の我が国の急激な人口減少に対応す心゙く「地方創生」が期待 されており，国は，地方創生政策として結婚・出産・子育て支援に 関わるサービスや, 地域課題解決に向け地域の企業等の多様な主 体の協働による共助社会づくりを推進している1)。

地方創生の考えでも期待されているソーシャルビジネス（う地 域課題解決型）事業の展開や地域発イノベーションの創出等の新 たな「しごと」づくり 12) に呼応し，例えば，子育てコミュニティ の形成を重視し, 安心して子育てを楽しめる賃貸住宅の商品開発 を民間企業が単独で行う事例 3)や，子ども見守りの共助機能構築 を目指す造成地販売を行うハウスメーカー4)が，CSV (Creating Shared Value : 共通価值の創造) 5)を目指して「住宅が変われば社 会が変わる」を掲げ企業経営を行う事例のように，新ビジネスの 展開や業態变革を検討・実施している状況にある。造園業やその 他の造園フィールドに参入する民間事業者においても，都市公園 等において子育て支援サービス等の地域課題解決型事業の展開を 萌芽的ながら検討・実施している実態が明らかになっている67)8)。 今後, 造園業においても，このような地方創生に資する都市公園 の新たな役割に対応し, 新たな「しごと」づくりも視野に入れなが ら, 子育て支援や共助に関わる管理目標やそれに対応した重要業 績評価指標（以下, KPI）を設定し, 公園・地域の物的・人的資源 を有効活用しつつ，パークマネジメント業務を遂行できることが 求められ, 寸なわち, 「造園業の業態变革」が期待されている 911011)。

本研究の調査対象地である, 富山県舟橋村においては, 富山市の ベッドタウンとして人口が増加しているが, 転入してきた新住民 とのコミュニティ形成には課題があり ${ }^{12}$ ，共助機能の低下や人口 増加に伴う地価の割高による宅地供給の減退等から, 将来的には 人口が減少することが懸念されている。これらの課題の解決策と して「子育て支援」と「共助」に着目したまちづくりの展開により， 村内の出生数の向上 (KPI : 40 世帯/5 年間), 子育て世代の転入促 進 (KPI : 149 人 5 年間) 等を目標に, 村内における人口減少克服
への取組を進めている 13114115)。

具体的には, 公園, 保育園や賃貸住宅等を配置した「子育て共助 型モデルエリア」を形成し，モデルエリアや周辺施設において，行 政，ハウスメーカー，建設コンサルタント，土木・造園業，保育サ 一ビス業や情報通信事業等の県内外の企業の連携，村民参加型の 子育て支援等を行うことにより，子育てに対する不安・負担の解 消等を図り，KPI の達成を目指している（図-1）13141415)。

また, モデルエリア内の近隣公園の指定管理業務においても, 従 来型の植栽の管理業務を中心とした「仕様発注」から，民間が自ら 人口減少時代に対応した子育て環境や共助に関わる管理目標の設 定や KPI 等の達成を求める「性能発注」を始めており，これも， 前述したような都市公園の新たな役割に対応した「造園業の業態 変革」を促す動きといえる2)1617)。

以上のような，地方創生に資する都市公園の新たな役割を見据 えた性能発注にも対応できるような造園業の業態変革が求められ る状況のもと，そのような状況に対応した研究として，人口減少 克服や地域課題解決に関わる新たな目標設定に対応した施設マネ ジメントの可能性を検討するようなソーシャルマーケティングの 観点からの研究 11)18)や，地域課題解決型事業に着目した造園業や 造園フィールドを活用した CSVやビジネスの観点からの研究 6)778) 等が行われている。

特にソーシャルマーケティングの観点からの研究 1118)では, 子 育て支援サービスによる施設の管理目標として，一般に重要視さ れる目標である「利用増進 (リピート意向)」に加え, 利用者の「共 助や定住・転入に資する意識変化」等の地方創生や，人口減少克服 に資する波及の可能性の解明がなされてきた。

一方で，人口減少克服に関わる KPI を掲げ，その達成に向けた 「子育て支援」と「共助」のまちづくり，モデルエリアにおける取 り組みを行う先進的な事例を対象に，実際に，このような取り組 みやマネジメントによる KPI の影響, すなわち，因果連鎖を共 分散構造分析等により可視化し, その可視化した情報を実務者 (行

*大阪経済大学人間科学部 
政等) へフィードバックすることを念頭に, 実際の KPI の達成に 向けた施設やモデルエリア等のマネジメントの可能性や方向性等 について検討した研究はみられない。

そこで本研究では, 先進事例として位置づけられる富山県舟橋 村の現状の子育て共助型モデルエリアや，その周辺施設のマネジ メントを対象に，そのサービスに対する利用者の満足度と，人口 減少克服に関わる KPI の達成に寄与するサービス利用による意識 等の変化との関係, 寸なわち, 因果連鎖を解明し, 人口減少克服に 向けた子育て共助型モデルエリアの可能性やマネジメントの方向 性を検討すること, 造園業の新たな業態変革の考え方について検 討することを目的とする。

\section{2. 研究の方法}

\section{（1）調査対象サ一ビスの選定および概要}

本研究では, 調査対象地である富山県舟橋村の子育て支援セン ター「ぶらんこ (以下, 施設)」を含めたモデルエリア周辺におけ る一連の子育て支援サービスを調查対象サービスとした。アンケ 一ト調査の対象者は, 施設の利用者とした。なお, 施設で実施され る子育て支援サービスについては,「施設サービス」として位置づ けた。

富山県舟橋村は，面積 $3.47 \mathrm{~km}^{2}$ ，人口 3,152 人 (2019 年現在) の我が国で最も小さい村でありながら, 富山県の中心部である富 山市一鉄路で約 15 分と, 良好なアクセス性を持ち, ベットタウン として人口は増加傾向にあったが, 将来の年齢構成比や子育て世 代の転入数の減少を鑑みると, 人口減少 $(2060$ 年の転入なしの場 合の推計值 2,058 人）が危惧され, 前述の通り,「子育て共助まち づくり」政策を地方創生政策より立案し, 村内の出生数の向上等 の KPI を設定している 13)14115)。

舟橋村では, 村内に, 賃貸住宅, 認定こども園, 公園を配置した モデルエリア (都市計画未線引・用途地域なし) を形成し, その周 辺に施設や戸建て住宅等も立地している(図一-1)。モデルエリア を中心に，産学官金連携のもと，子育て世代の転入を促進する受 け皿となる子育てコミュニティ賃貸の建設や，子育て世代や団地 の中高年世代等のコミュニティ形成を促すために ICT を活用した 子育て支援サービスの実施，県内造園業の新たな仕事づくりを目 指したパークマネジメントの実施等の取り組みによって, 舟橋村 全体における前述した KPI の達成 (子育て世代の転入促進 (KPI : 149 人 5 年間) 等) を目指している 13)14115)。

なお, モデルエリア内の賃貸住宅は, 村直営であり, 戸数 20 戸, 現在 (2019 年時), 7 世帯の子育て世帯及び夫婦世帯が居住してい る。認定こども園は, 社会福祉法人が運営する民設民営の施設で あり, 常勤スタッフ 28 人, 園览数 (幼稚園・保育園機能合わせて) 145 人となっている。また, 公園は, 近隣公園 (3.45ha) であり造 園業が指定管理者となっており, 小学生 (子供公園部長 9) ) がクラ ウドファンディングで設置した遊具が設置されている 13)14115)。

次に, 施設サービスについて整理すると, 施設は, 村直営の子育 て支援施設であり，利用者の得意分野を活かし，母親が講師とな り教室を開講することや，演奏会にて聞く側ではなく演奏者とし て「参加」し，参加者と「交流」や「コミュニケーション」を促す 等, 利用者が直接関わる余白を設けることで，場に対する愛着を 持たせると同時に，意見を言いやすい，反映されやすい場づくり を図っている。また, 保育士, 助産師, 中学校や小学校等の周辺地 域の団体個人との「外部連携」事業を実施し, 施設外の環境におけ る見守り体制の実現を目指している。さらに，施設において活動 している「ボランティア」チーム「さくらんぼくらぶ (任意団体)」 は，上述したような「参加・交流」や「コミュニケーション」等を 重視する施設サービスの考え方を理解しながら, 保育士以外のボ ランティアや様々な業種でも参入可能と考えられる「専門性の低

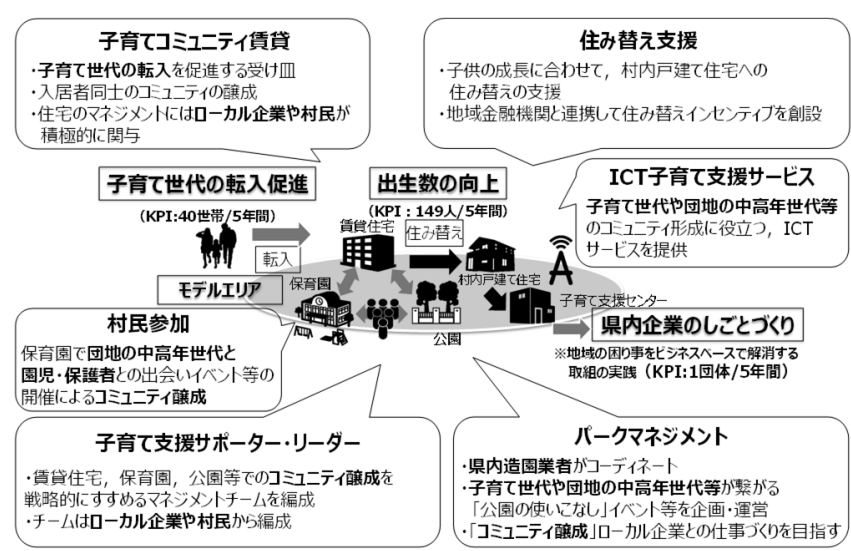

図-1＼cjkstart富山県舟橋村の子育て共助のまちづくり
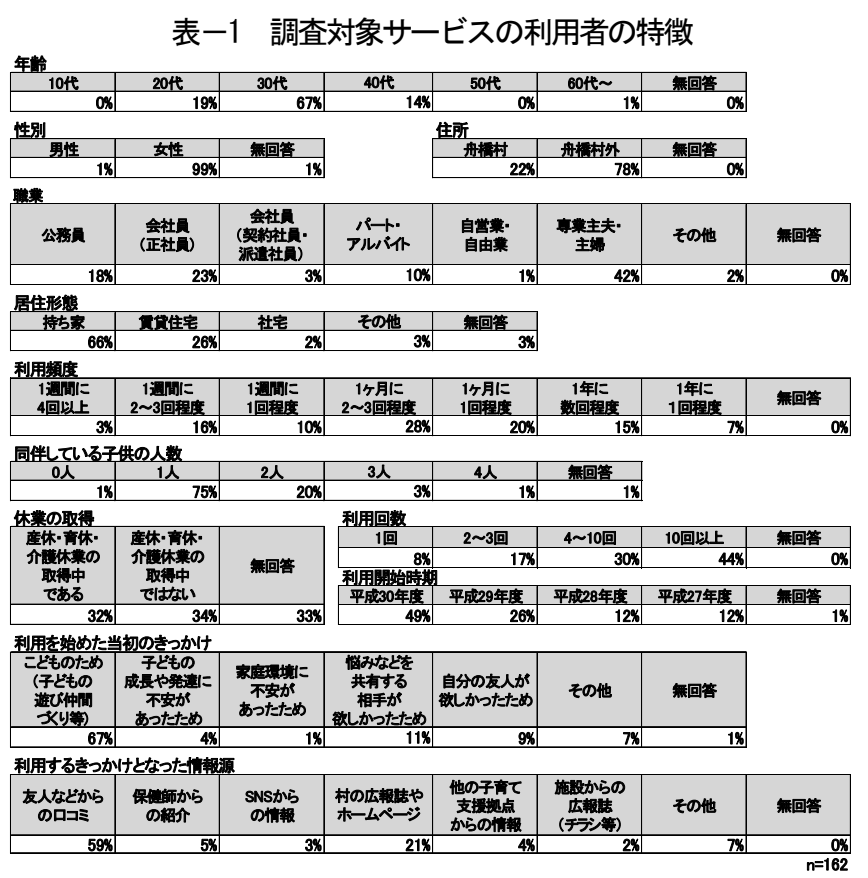

い」プログラム (お花見, スイカ割り, クリスマス会やお餅つき会 等）を週に 1 回実施し，参加者の「子育ての楽しさ」や，施設サ 一ビスの利用者の「参加・交流」を促す中継役として，子どものた めだけではなく母親のためのイベントを実施することにより親同 士の交流等の「コミュニケーション」を促していること等が特徵 として挙げられる ${ }^{12)}$ 。

以上のような取り組み・仕組みづくりが, 調査対象地における子 育て支援（育児）や「共助」を通じた KPI の達成に寄与する意識 (定住・転入意向) 等の変化に影響寸ると考えられることから, 本 施設で提供されるサービスを調査対象サービスとして選定した。

\section{（2）調査対象サービスに対する利用者の意識調査}

本研究では, 研究の背景及び目的に対応すべくソーシャルマー ケティングの観点からの調査・分析を実施する。すなわち, 調査対 象サービスに関わる各種要因 (原因系) から, サービス利用による 各種の影響 (結果系) に至る顧客満足モデルの設定と，一連の因果 連鎖を解明し，それにより，子育て支援サービスによる結果要因 (施設及びモデルエリアの管理目標) として利用者の「共助や定 住・転入に資する意識変化」への波及の可能性を解明する。

まず，調査対象サービスの利用者の意識を把握するため，施設 （ぶらんこ）の利用者に対しアンケート調査を実施した。

アンケートの調査項目は「回答者属性」に加え,「調査対象サ一 ビスに対する要因別満足度」, 調査対象サービスに対する「総合満 足度」,「今後のサービスの利用意向等」, 及び利用者の「サービス 
利用による意識等の変化」である。

回答者属性については,「年齢」,「性別」,「職業」,「居住形態」, 「同伴している子供の人数」,「利用回数」,「利用開始時期」,「利用 頻度」, 「利用を始めた当初のきっかけ」, 「利用するきっかけとな つた情報源」等について尋ねた。

調査対象サービスに対する要因別満足度については, 施設サー ビスである, 子育て支援センター「ぶらんこ」のサービスに関する 項目（表-1の要因別満足度に記載する 20 項目）と, 調査対象节 ービスに対する「総合満足度（『調査対象サービス』全体としての 総合的な評価)」を列記し, それぞれの項目について 7 件法 19)の選 択肢を示し, 単項選択により調査対象サービスに対する要因別満 足度及び総合満足度について尋ねた。

サービス利用による意識等の変化については，利用者の共助や 定住・転入に資寸る意識変化と関わる「子育て」，「交流」，「地域愛 着」,「共助意向」，「定住・転入」や「支援意向」に対する意識等の 変化に関寸る項目を列記し, それぞれの項目のサービス利用後の 変化を, 7 件法 19)の選択肢を示し, 単項選択によりそれらの意識 等の変化について尋ねた。

実査は, 2018 年 12 月〜2019 年 1 月の期間における調査対象サ 一ビスの利用者（親）及び過去 3 年間の調査対象サービスの利用 者（親）に直接配布・回収法で実施した。配布数は 288 件，有効 回答数は 162 件（有効回答率 $56 \%$ ） となった。

\section{（3）調査対象サ一ビスの利用者の意識構造・変化の把握}

2.（2）で得られたデータを分析して, 調査対象サービスの利用 者の評価構造モデルを構築し, それに基づき, 利用による「調査対 象サービスに対する満足度因子」から「サービス利用による意識 等の変化」への波及の可能性等を定量的に明らかにした。

具体的には，「回答者属性」に対しては単純集計を実施し，「施設 サービスに対する要因別満足度」,「サービス利用による意識等の 変化」に対しては因子分析を実施し, それらの結果を踏まえつつ, 共分散構造分析を用いて調査対象サービスに対する利用者の意識 構造モデルを構築した。

\section{3. 結果および考察}

\section{（1）調査対象サ一ビスの利用者の特徵}

調査対象サービスの利用者の特徵をみると, 性別は, 「女性」が 99\%であること，年齢は，「30 代」が 67\%であること，職業は，

「専業主夫・主婦」が $42 \%$ あるること，住所は，「舟橋村外」が $78 \%$ であること，居住形態は，「持ち家」が 66\%であり，住所が 「舟橋村外」かつ「持ち家」が 50\%であること，休業の取得は， 「産休・育休・介護休業の取得中ではない」が $34 \%$, 同伴してい る子供の人数は，「 1 人」が $75 \%$ であること, 利用回数は, 「10 回 以上」が $44 \%$ であること, 利用開始時期は, 「平成 30 年度」が $49 \%$ であること, 利用頻度は, 「1 カ月に $2 \sim 3$ 回程度」が $28 \%$ である こと，利用を始めた当初のきっかけは，「子どものため（子どもの 遊び仲間づくり等)」が $67 \%$ であること, 利用するきっかけとなっ た情報源は，「友人などからの口コミ」が $59 \%$ であること等が把握 された（表一1）。

\section{(2) 調査対象サ一ビスに対する利用者の満足度}

まず, 得点化 (7 点満点) 19) した調查対象サービスに対する総合 満足度の平均得点をみると， 5.6 点であることが把握された。

調査対象サービスの利用者の施設サービスに対する要因別満足 度及びそれに対する因子分析の結果を表一 2 に示す。

次に, 利用者の要因別の評価実態を把握するために得点化 (7 点 満点）19）した利用者の施設サービスに対する要因別満足度の平均 得点をみると,「スタッフの親しみやすさ・身近さ (6.2 点)」, 「ス タッフの人数・連携体制 (6.0 点)」, 「自らも気軽に参加出来る手 作り感のあるイベント (5.8 点)」, 「スタッフの専門知識・信頼度
表一2 調査対象サ一ビスの利用者の施設サ一ビスに対する 要因別満足度及びそれに対する因子分析（パターン行列）

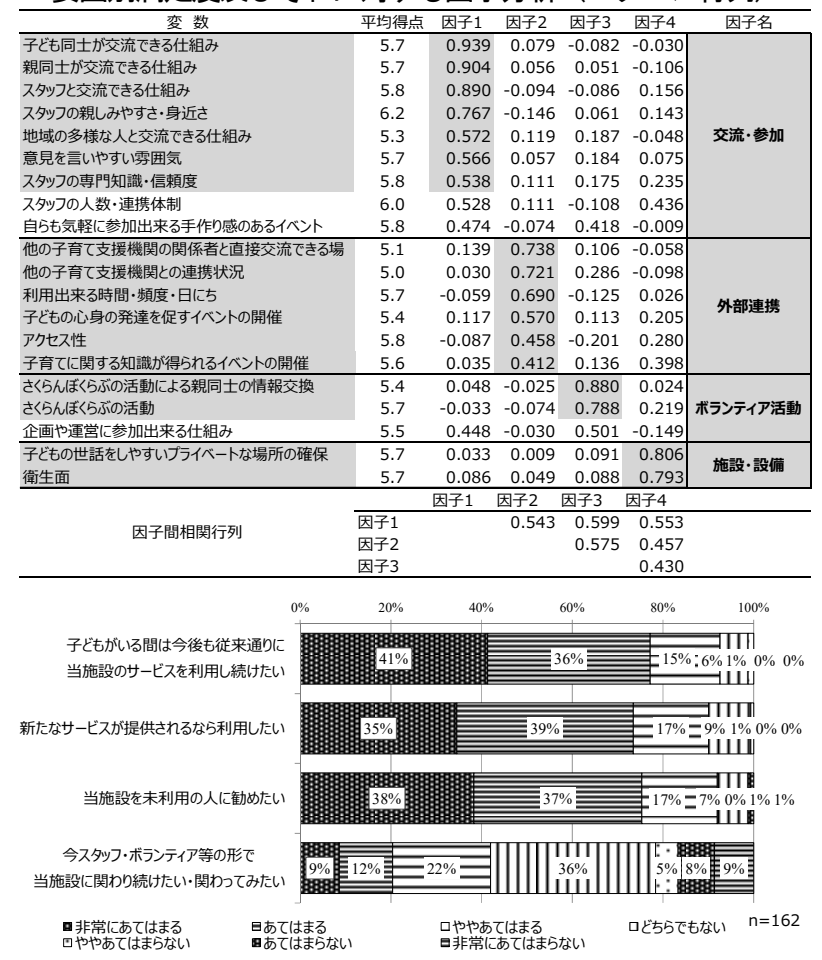

\section{図一2 利用者の今後のサービス利用意向等}

\section{表-3 調査対象サ一ビスの利用者のサービス利用による 意識等の変化の因子分析 (パターン行列)}

\begin{tabular}{|c|c|c|c|c|c|c|c|}
\hline 変数 & 平均得点 & 因子1 & 因子2 & 因子3 & 因子4 & 因子5 & 因子名 \\
\hline 舟橋村におけろ持ち家意向が強まった & 4.0 & 1.026 & -0.018 & -0.021 & -0.006 & -0.084 & \multirow{6}{*}{ 定住-転入意向 } \\
\hline 舟橋村への転入意向が向上した & 4.1 & 0.896 & 0.016 & -0.006 & 0.070 & -0.097 & \\
\hline 舟橋村への定住意諢力強まつた & 4.0 & 0.855 & -0.023 & -0.032 & -0.069 & 0.169 & \\
\hline 他の子どもの見守りや活動の補助をしたい気持ちが強まつた & 4.4 & 0.475 & 0.067 & 0.107 & 0.131 & 0.127 & \\
\hline 舟橋村における子育て支援活動への参加意向力強まつた & 4.8 & 0.460 & 0.362 & -0.021 & -0.014 & 0.121 & \\
\hline 舟橋村以外での子育て支援活動への参加意向力強まうた & 4.6 & 0.262 & 0.193 & 0.175 & 0.084 & 0.106 & \\
\hline 子育て支援活動への興味·関心か増加した & 5.4 & -0.038 & 0.811 & 0.042 & -0.002 & 0.149 & \multirow{4}{*}{ 育児·共助 } \\
\hline 子育てに関する知識·技術力増加した & 5.1 & -0.028 & 0.761 & -0.033 & 0.227 & -0.095 & \\
\hline 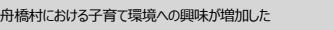 & 5.6 & 0.063 & 0.749 & 0.123 & -0.138 & 0.102 & \\
\hline 子育にに対する自信·安心感加增加した & 5.3 & 0.040 & 0.720 & 0.131 & 0.035 & -0.064 & \\
\hline 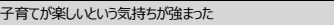 & 5.6 & -0.039 & 0.023 & 0.972 & -0.030 & 0.021 & \multirow{5}{*}{ 子育ての楽しさ } \\
\hline 自分の子どもへの愛情力強まつた & 5.7 & -0.059 & 0.050 & 0.907 & -0.038 & 0.020 & \\
\hline 子育てにゆセりが生まれた & 5.4 & 0.033 & 0.149 & 0.678 & 0.074 & 0.020 & \\
\hline 自分の子育ての経験力゙他の親の子育ての役に立つた & 4.9 & 0.044 & 0.154 & 0.454 & 0.177 & -0.012 & \\
\hline もう一人子どもを持ちたいと思った & 4.8 & 0.149 & 0.036 & 0.351 & 0.339 & -0.085 & \\
\hline 当施設外厄も交流する友人数が増加した & 4.6 & -0.068 & 0.256 & -0.047 & 0.755 & -0.079 & \multirow{6}{*}{ コミュニケーション } \\
\hline 所属コシュニテ擞が増玑た & 3.8 & 0.001 & 0.028 & -0.022 & 0.652 & 0.121 & \\
\hline 仕事場な゙゙の家庭以外の場所ての生産性が向上した & 4.2 & -0.047 & 0.015 & 0.004 & 0.634 & 0.203 & \\
\hline 近所付さ合いが滑化した & 3.8 & 0.188 & -0.199 & 0.050 & 0.565 & 0.232 & \\
\hline 家庭内のコシューケーショシが円滑化した & 4.5 & 0.136 & -0.035 & 0.327 & 0.468 & 0.043 & \\
\hline 当施設内で会話できる友人数が増加した & 5.0 & 0.123 & 0.235 & 0.205 & 0.431 & -0.138 & \\
\hline 住んている地域に対する愛着力゙堌した & 4.5 & -0.008 & 0.014 & 0.071 & 0.028 & 0.884 & \multirow{2}{*}{ 地域愛着 } \\
\hline 住んている地域への興味・関心か兽した & 4.5 & 0.076 & 0.061 & -0.061 & 0.148 & 0.771 & \\
\hline \multirow{5}{*}{ 因子間相関行列 } & & 因子1 & 因子2 & 因子3 & 因子4 & 因子5 & \\
\hline & 因子1 & & 0.464 & 0.456 & 0.571 & 0.485 & \\
\hline & 因子2 & & & 0.628 & 0.550 & 0.362 & \\
\hline & 因子3 & & & & 0.594 & 0.422 & \\
\hline & 因子4 & & & & & 0.455 & \\
\hline
\end{tabular}

(5.8 点)」, 「スタッフと交流できる仕組み (5.8 点)」, 「アクセス 性（5.8 点）」が比較的高い一方，「他の子育て支援機関との連携状 況 (5.0 点) 」, 「他の子育て支援機関の関係者と直接交流できる場 (5.1 点)」が比較的低い值を示した。

また，20 項目の施設サービスに対する要因別満足度の評価結果 について因子分析（主因子法，プロマックス回転）を実施し，ガッ トマン基準の観点で検討した結果，4因子が抽出された。

以下に，抽出した各因子に関わる因子負荷量の值の高い項目を もとに各因子の解釈を行った。

まず, 施設サービスに対する利用者の要因別満足度については, 因子 1 は，「子ども同士が交流できる仕組み」，「親同士が交流でき る仕組み」,「スタッフと交流できる仕組み」の項目の值が高いこ 


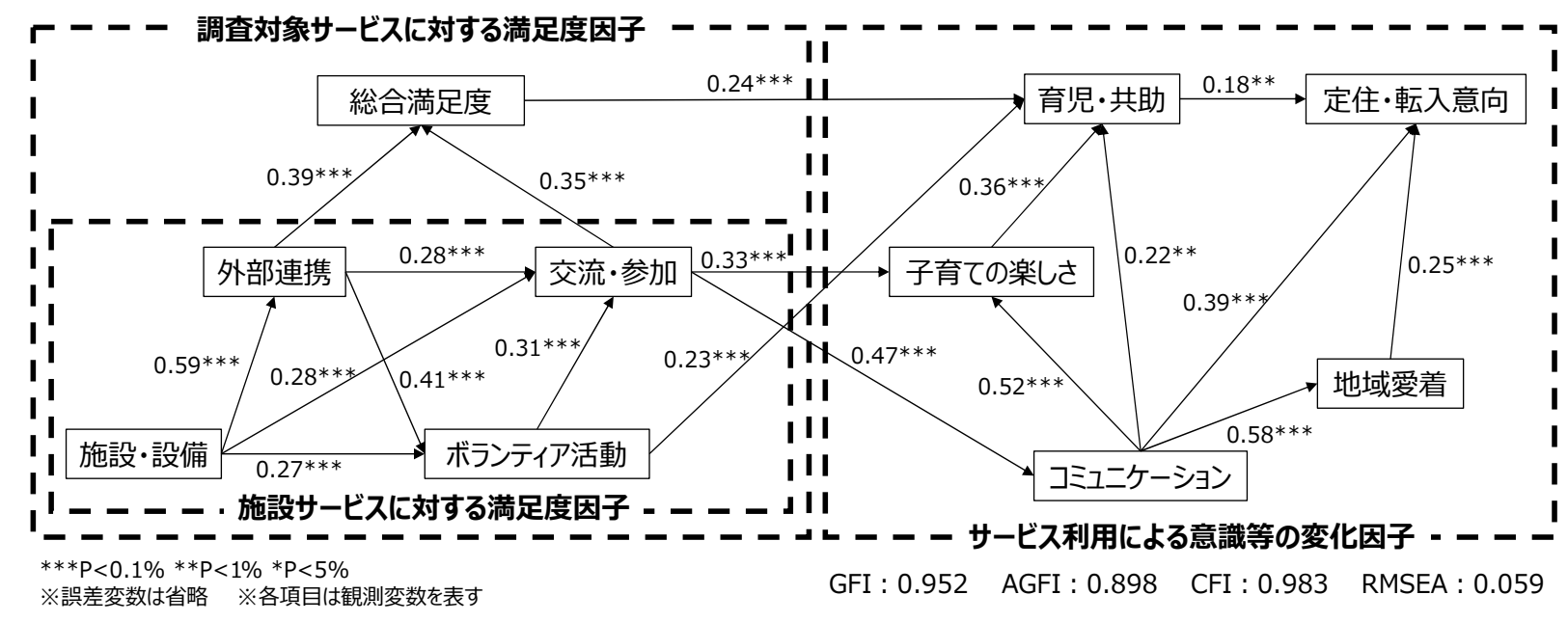

図一3 調査対象サービスに対する利用者の評価構造モデル

とから「交流・参加」と解釈した。

因子 2 は，「他の子育て支援機関の関係者と直接交流できる場」, 「他の子育て支援機関との連携状況」の項目の值が高いことから 「外部連携」と解釈した。

因子 3 は,「さくらんぼくらぶの活動による親同士の情報交換」, 「さくらんぼくらぶの活動」の項目の值が高いことから「ボラン ティア活動」と解釈した。

因子 4 は，「子どもの世話をしやすいプライベートな場所の確 保」, 「衛生面」の項目の值が高いことから「施設・設備」と解釈し た。

以上より, 施設サービスの利用者の意識として「施設サービスに 対する満足度」の因子分析から「交流・参加」,「外部連携」,「ボラ ンティア活動」,「施設・設備」の 4 つの因子 (以下，「施設サービ スに対する満足度因子」) で捉えられることが把握された (表一2)。

\section{（3）利用者の今後のサービスの利用意向等}

利用者の今後のサービスの利用意向等を図一 2 に示す。

「従来通りにサービスを利用し続けたい」は，「非常にあてはま

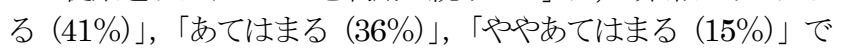
あることが把握された。

「新たなサービスが提供されるなら利用したい」は，「非常にあ てはまる (35\%)」,「あてはまる (39\%)」,「ややあてはまる (17\%)」 であることが把握された。

「サービス未利用の人に薦めたい」は, 「非常にあてはまる (38\%)」, 「あてはまる (37\%)」, 「ややあてはまる (17\%)」であ ることが把握された。

「スタッフ・ボランティアなどの形で当施設に関わりたい」は,

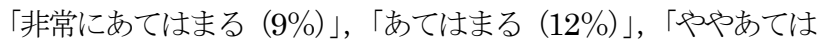

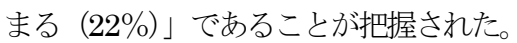

\section{（4）利用者のサ一ビス利用による意識等の変化}

調査対象サービスの利用者のサービス利用による意識等の変化 の評価及びそれに対する因子分析の結果を表一 3 に示す。

まず, 得点化 (7 点満点) 19) した調査対象サービスの利用者のサ 一ビス利用による意識等の変化の平均得点をみると, 「自分の子ど もへの愛情が強まった（5.7 点)」,「舟橋村における子育て環境へ の興味が増加した（5.6 点)」, 「子育てが楽しいという気持ちが強 まった (5.6 点)」の值が比較的高い一方, 「所属コミュニティ数が 増加した (3.8 点)」, 「近所付き合いが円滑化した (3.8点)」, 「舟 橋村における持ち家意向が強まった (4.0 点)」が比較的低い值を 示した。

次に, 調査対象サービスの利用者のサービス利用による意識等 の変化の評価結果について因子分析（主因子法，プロマックス回
転）を実施し，ガットマン基準の観点で検討した結果，5因子を抽 出した (表一3)。

以下に，抽出した各因子に関わる因子負荷量の高い項目をもと に各因子の解釈を行った。

因子 1 は，「舟橋村における持ち家意向が強まった」，「舟橋村へ の転入意向が向上した」，「舟橋村への定住意識が強まった」の項 目の值が高いことから「定住・転入意向」と解釈した。なお，因子 1 については，「他の子どもの見守りや活動の補助をしたい気持ち が強まった」や「舟橋村における子育て支援活動への参加意向が 強まった」等の共助意識に資する意識変化に関する項目も含まれ, このことから，「共助意識」を背景とした「定住・転入意向」であ ると考えられる。

因子 2 は，「子育て支援活動への興味・関心が増加した」，「子育 てに関する知識・技術が増加した」，「舟橋村における子育て環境 への興味が増加した」の項目の值が高いことから「䏍児・共助」と 解釈した。

因子 3 は，「子育てが楽しいという気持ちが強まった」，「自分の 子どもへの愛情が強まった」の項目の值が高いことから「子育て の楽しさ」と解釈した。

因子 4 は, 「当施設外でも交流する友人数が増加した」,「所属コ ミュニティ数が増加した」,「仕事場などの家庭以外の場所での生 産性が向上した」の項目の值が高いことから「コミュニケーショ ン」と解釈した。

因子 5 は, 「住んでいる地域に対する愛着が増した」,「住んでい る地域への興味・関心が増した」の項目の值が高いことから「地域 愛着」と解釈した。

以上より, 調査対象サービスの利用による意識変化として「利用 者のサービス利用による意識等の変化」の因子分析から「定住・転 入意向」,「育児・共助」,「子育ての楽しさ」,「コミュニケーショ ン」,「地域愛着」の 5 つの因子（以下，「サービスの利用による意 識等の変化因子」）で捉えられることが把握された（表一 3 )。

\section{（5）サ一ビス利用者の意識構造モデル}

これまで整理してきた，3.（2）で分析した「調査対象サービス に対寸る満足度因子」を「原因系」, 利用者の「共助や定住・転入 に資する意識变化」として，3．（4）で分析した「サービス利用に よる意識等の変化因子」を「結果要因」とする「結果系」と位置づ け，調査対象サービスに対するサービス利用者の意識構造モデル を構築した。

モデルの構築にあたり, 各観測変数は, 以下のように設定した。 まず，「施設サービスに対する満足度因子」及び「サービス利用に よる意識等の変化因子」については，3．（2），3．（4）で得られた 
各因子について, 各調査項目において最も因子負荷量の絶対值が 大きい因子に分類し (表 -1 , 表-2の各因子の網かけ部分の項目), 各因子に対応した尺度を構成する項目として抽出して，因子ごと に項目の得点を単純加算することで, モデルを構成する「調査対 象サービスに対する要因別満足度」,「サービス利用による意識等 の変化」に関する尺度を構成した。各尺度の $\mathrm{a}$ 係数はいずれも 0.8 を上回っており, 一定の内的一貫性を有しているため, 尺度とし て使用することとした ${ }^{20)}$ 。

2.（1）より，施設サービスを含む調査対象サービスが調查対象 地における KPI の達成に寄与するサービス利用による意識等の変 化に影響するという仮説に基づき，モデルの適合度とパス係数の 優位性を検討した上で採択した因果モデルは，図一3である。

具体的には，これまでの調查対象サービスの実態調査 12)13114)15) 等で得られた知見に基づき，「調査対象サービスに対する満足度因 子 (原因系)」から「サービスの利用による意識等の変化因子」へ の波及を「結果要因」とした「結果系」に至る評価構造モデルを構 築して共分散構造分析を行い, モデルのデータへの適合度を確認 して最終的なモデルを決定した ${ }^{21)}$ 。

パス係数は, 標準解で, パス係数の大きさは相対的な関係の強さ を示しており, すべてのパス係数が統計的に有意である。また, 採 択した連関モデルは, $\mathrm{GFI}=.952, \mathrm{AGFI}=.898, \mathrm{CFI}=.983$, RMSEA = 059 であり, GFI と CFI は 0.9 以上の十分な適合を示 し, AGFI は適合度のよさの目安とされている 0.9 を下回ってい るが一定の適合度に達しており, RMSEA も適合度の悪さの目安 とされている 0.1 を下回っていることから, 構築したモデルは採 択できると判断した ${ }^{22)}$ 。

これより，「施設サービスに対する満足度因子」，「調査対象サー ビスに対する満足度因子」,「サービス利用による意識等の変化因 子」の間で因果関係があることが把握された。

具体的には, 主に, KPI の達成に寄与する「結果系」である「定 住・転入意向」や「育児・共助」への因果連鎖の解明の視点から整 理すると,「定住・転入意向」へは,「コミュニケーション (パス係 数 (以下, 同様) 0.39), 「地域愛着 (0.25)」,「育览・共助 (0.18)」 の順に影響が大きいこと,「定住・転入意向」への影響が比較的大 きい「地域愛着」は，「定住・転入意向」への直接的効果も大きか った「コミュニケーション $(0.58) 」 の$ 影響が大きいこと，また， 「育児・共助」へは,「子育ての楽しさ (0.36)」,「総合満足度 $(0.24) 」$, 「ボランティア活動 (0.23)」, 「コミュニケーション $(0.22) 」$ の順 に影響が大きいこと，「育児・共助」への影響の大きい「子育ての 楽しさ」には,「コミュニケーション (0.52)」,「交流・参加 (0.33)」 の順に影響が大きいこと, また, 同様に「育児・共助」への影響の 大きい「総合満足度」には,「外部連携 (0.39)」,「交流・参加 (0.35)」 の順に影響が大きいこと, 総合満足度へ影響する「外部連携」には, 「施設・設備 $(0.59) 」 の$ 影響が大きいこと, 同様に総合満足度へ 影響する「交流・参加」には，「㕕児・共助」への影響も大きい「ボ ランティア活動（0.31）」の影響が大きいこと等が把握された。

\section{4. 考察}

\section{（1）利用者の評価構造モデルの観点からみた調査対象地におけ} る人口減少克服に向けた子育て共助型モデルエリアの可能性

ここまで検証した，「調査対象サービスに対する満足度 (原因系)」 から「サービス利用による意識等の変化」への波及を結果要因と した「結果系」に至る評価構造モデル (図一-3), 寸なわち, 可視化 された因果連鎖を整理し直し,「子育て環境 (育児)」や「共助や定 住・転入に資する意識変化」を管理目標とした調査対象サービス の可能性について検討寸る 23$) 。$

まず，3．（5）で採択した評価構造モデルから, 調査対象地にお いては，「サービス利用による意識等の変化因子」であり，KPIの
達成に寄与する「定住・転入意向」に向け,「コミュニケーション」, 「地域愛着」,「育児・共助」を高めることが有用であること, 同様 にKPI の達成に寄与する「育児・共助」に向けては，「子育ての楽 しさ」, 「総合満足度」,「ボランティア活動」,「コミュニケーショ ン」を高めることが有用であることが把握された。

次に，「育児・共助」への影響の大きい「子育ての楽しさ」に向 けては，「コミュニケーション」，「交流・参加」を高めることが有 用であること，同様に「育児・共助」への影響の大きい「総合満足 度」に向けては,「外部連携」,「交流・参加」を高めることが有用 であることが把握された。また，「外部連携」「「交流・参加」を高 めるには，「施設・設備」や「育児・共助」への直接的な影響も大 きい「ボランティア活動」を高めることが有用であることが明ら かとなった。

上述したような因果連鎖から調查対象サービスの可能性等につ いて整理すると，まず，「サービス利用による意識等の変化因子」 のうち，「育児・共助」が共助意識を背景とした「定住・転入意向」 に寄与していることが把握され，調査対象地の「子育て共助」に着 目したまちづくりの展開が，村内の出生数の向上（KPI : 40 世帯 15 年間), 子育て世代の転入促進 (KPI : 149 人 5 年間) に寄与す ることが確認された。

また，「定住・転入意向」に寄与寸る「地域愛着」とも関わりの 強い「コミュニケーション」や「育児・共助」を管理目標とするこ とが重要であることが把握された。

特に管理目標として重要となる「育児・共助」の意識等の変化の ためには,「子育ての楽しさ」,「総合満足度」,「ボランティア活動」,

「コミュニケーション」を促す仕組みづくりが重要となるが，因 果連鎖を踏まえると，「ボランティア活動」を高めつつ,「交流・参 加」を介し，「コミュニケーション」や「子育ての楽しさ」を高め,

「育児・共助」を高める仕組みと, 調査対象サービスに対する総合 満足度を高め「育児・共助」を高める 2 つの取り組みが重要となる。

具体的に，舟橋村における前者の取り組みとしては，2.（1）で 示したような「ボランティア活動（さくらんぼくらぶ）」による,

「意見を言いやすい，反映されやすい場づくり（(例）母親が講師 となる教室)」のような「交流・参加」を促すプログラムの実施が,

「コミュニケーション」や「子育ての楽しさ」のような意識等の変 化を促す重要な取り組夕になっていると考えられる。また，舟橋 村における後者の取り組みとしては，総合満足度に影響する「交 流・参加」を促寸前者のような取り組みに加え, 同様に総合満足度 に影響する「外部連携」に寄与する 2. (1) で示したような保育士, 助産師, 中学校や小学校等の周辺地域の団体個人との連携事業の 実施による施設外の環境における見守り体制等の取り組みが重要 になっていると考えられる。

このように, 調查対象地の「子育て共助」に着目したまちづくり の目標設定や施設サービスは，KPI の達成に向けて現時点におい て成功していることが確認された。

\section{（2）利用者の評価構造モデルの観点からみた造園業の業態変革}

\section{の可能性}

調査対象地においては, 前述した通り, モデルエリア内の近隣公 園の指定管理業務においても，「性能発注」が行われる中，子育て 支援, 小学生 (子供公園部長 ${ }^{9}$ ) やその親, 地域住民, あるいはク ラウドファンディング等による共助意識をもつ人材を活用するよ うな,「ボランティア活動」や「交流・参加」を促す取り組みを実 施している 12)15)が，これらの取り組みも KPI の達成に寄与寸るこ とが示唆された。

したがって, 造園業も, 人口減少時代に対応した子育て環境や共 助に関わる管理目標の設定や KPI 等の達成を目指寸必要がある中, 本研究で得られた利用者の評価構造モデル（因果連鎖）を想定し ながら, 例えば, 専門性の比較的低い, 造園業も参入可能と考えら 
れる「コミュニティ形成」や「子育ての楽しさ」という中間アウト カム (管理目標) を念頭に, 造園のもつ自然資源の活用等の知識・ 技術を活かしつつ，調査対象地で展開されている「ボランティア 活動」や「交流・参加」に資する取り組みを行うことが有用かつ可 能であることが確認された。

調查対象地においては，「性能発注」を行ったことが，前述した ような都市公園の新たな役割に対応した造園業（指定管理者）の 業態変革を促したが，実際には，指定管理者は，当初，KPI 等に 対応した新たな業務のあり方について悩んでいること ${ }^{24)}$ 等も明ら かになっている。そのような状況のもと, 大学, 行政等が勉強会を 実施したことで，上述したような KPI に対応したパークマネジメ ント実施に至っており，今後は，本研究で明らかとなった実務者 も理解しやすい可視化された因果連鎖モデルを，実務者一情報提 供しつつ，その情報をもとにモデルエリア内のマネジメントの見 直しや新たな政策立案を行う予定である。

このように, 今後, 人口減少克服に向けたパークマネジメントを 行えるような造園業の業態変革に向けては，本研究で行ったよう な, 実務者である行政や造園業が理解しやすい可視化された因果 連鎖モデルを大学等が調査し, 実務者へフィードバックする仕組 みづくりが有効と考えられる。

\section{5. おわりに}

本研究では, 先進事例として位置づけられる舟橋村の現状の子 育て共助型モデルエリアのマネジメントを対象に，そのサービス に対する利用者の満足度と, サービス利用による意識等の変化と の関係 (可視化した因果連鎖) を解明し，人口減少問題の解決に向 けた子育て共助型のモデルエリアの可能性や造園業の新たな業態 変革の可能性について検討した。

以下に, 今後の課題として, 今回明らかとなった, 調査対象サ一 ビスの利用者の評価構造モデルについても, 調査時の評価構造で あり, サービスの見直しや継続的なサービス利用によりこの構造 も変化することから, 継続的な調査実施を行うことが期待される と同時に, 大学, 科学者が現実社会を客観視して研究対象とする のではなく, 社会のステークホルダーと結びつき協働・企画を行 う研究アプローチが期待される中 25$)$, 本研究のようにステークス ホルダーである実務者へ情報をフィードバック寸ることを通し, マネジメント上の課題に対応した研究を行うことが造園学にも期 待されると考えられる。

謝辞: 本研究の遂行にあたり，舟橋村の吉田昭博氏，廣瀬美歩氏， 舟橋村の公園の指定管理者である（有）金岡造園の金岡伸夫氏に は，アンケート調査やヒアリング調査に関して多岐にわたるご協 力をいただいた。ここに厚く感謝する次第である。

\section{補注及び引用文献}

1）内閣府 : まち・ひと・しごと創生基本方針 2017 : 首相官邸ホームページ < httpsi//wwwkanteigo.jpjp/singi/souseifinfo/pdfh29-06-09-kihonhousin2017hontaipdf>, 2017.12.26 更新, 2017.12.30 参照

2) 国土交通省 (2015): 国土形成計画 (全国計画) : 国土交通省ホームページ < http://www.mlit.go.jp/common/001100233.pdf>2015.8.15 更新, 2016.9.14参照

3）旭化成不動産レジデンス: 子育て共感賃貸住宅 ヘージルメゾン「母力」: 旭化成不 動産レジデンスホームページ

< https://www.afr-web.co.jp/hebel-rooms/feature/boriki/support/index.html >, 2019.9.23 更新, 2019.9.23 参照

4) 積水ハウス (株) : 洒值創造のビジョンと戦略「中期経営計画と CSV 戦略」: 積水八 ウスホームページ

$<$ https://www.sekisuihouse.co.jp/sustainable/values/relevance/index.html >, 2017.9.6 更新, 2017.9.6 参照

5）マイケルE. ポーター・マーク R. クラマー (2011) : 共通価值の戦略 : ダイヤモン
ドハーバードビジネスレビュー 36 (6), $8-31$

6）市林恒士・今井涼太・小松曲紀子・塩見一三男・金剛省吾 (2018) : 共通価值の創造 の観点からみた造溒建設業による地域課題决型事業の展開に関寸る研究 : ランドス ケープ研究 81 (5), 521-526

7）金剛省吾・市村恒士・小松㘫紀子（2014）：富山県造園業のCSR 活動の現状からみた 経済的俩值と社会的俩值の一体的実現の可能性: ランドスケープ研究77 (5), 719724

8）塩見一三男・中川唀徳・小松西紀子・市村恒士・金剛省吾 (2019) : 民間事業者の意 識からみた「都市公園ビジネス」展開の可能性 : ランドスケープ研究 82 (5), $511-516$

9）金岡伸夫（2019）：公園は地方創生のシビルミニマム〜日本一小さな舟橋村「園电吋 びプロジェクト」の取り組み〜：ランドスケープ研究 83 (1), 54-55

10）国土交通省の町田誠氏による発言 (町田誠, 他 5 名（2018）: 公園緑地の新たなス テージ 都市公園法改正と公園における公民連携: 公園緑地78 (4) 16-26)

11）宮地創・市村恒士・金岡省吾 (2019)：地方創生に資する「都市公園での子育て支援 サービス」による利用者の意識変化: ランドスケープ研究 82 (5), 511-516

12）舟橋村へのヒアリング調査より。

13）舟橋村 : 舟橋村人口ビジョン・舟橋村総合戦略の目標・KPI : 舟橋村ホームページ $<$ https://funahashi-sosei.com/kpi.html>, 2019.7.25 更新, 2019.8.20参照

14）舟橋村: 舟橋村が目指寸地方創生のイメージ: 舟橋村ホームページ < https:/funahashi-sosei.com/sosei3.html>, 2019.7.25 更新, 2019.8.20 参照

15）金岡省吾・藤田敬人・吉田昭博・廣頼美歩・中井明日香 (2018)：「人口減少はビジ ネスチャンス 新たな地域づくりによる移住・定住一 “日本一小さい村”舟橋村を 実験場に “子育て共助” “CSV”て地方創生にコミット!一」：(富山大学芸術文化学 部紀要）都萬麻II，28-41

16）富山県舟橋村では，子育て共助のまちづくりを掲げる中，「舟橋村子育て支援モデル 事業推進に係るモデルエリア運営支援事業 等のプロポーザルにおいて, 仕様書に 要求水淮をいれた「性能発注」を行っている。舟橋村ホームページ < http://www.vill.funahashi.toyama.jp/wp/wp-content/uploads/2018/08/ model_bosyuu.pdf >, 2017.9.6 更新, 2018.8.8参照

17）国十交通省総合政策局（2016）：公共施設管理における包括的民間委託の導入事例 集 : 国土交通省ホームページ

< http://www.mlit.go.jp/sogoseisaku/Kanminrenkei/h25/h25-02.pdf >, 2019.7.25 更新, 2019.8.20参照

18）小松曲紀子・市村恒土・金岡省吾 (2016)：自然体験施設における雇客満足からみた新 規顧各の利用堌進およひ地域課題解决への波及: ランドスケープ研究79 (5)，589594

19）得点化は，「非常に満足／非常にあてはまる」:7 点,「満足/あてはまる」:6 点,「や や満足/ややあてはまる」: 5 点,「どちらでもない $: 4$ 点, 「やや不満/ややあては まらない $: 3$ 点,「不満/あてはまらない $: 2$ 点,「非常に不満/全くあてはまらな い: 1 点として得点化した。

20）クロンバックの $\alpha$ 係数のことで，尺度に含まれる項目が一致した傾向を測定してい るかを確認寸るための指標である。心理測定尺度の場合，0.8以上では信頼性が高い と解釈されるのが一般的である。

21）なお，利用者の「今後のサービスの利用意向等」も「結果系」として位置づけたモ デル構築についても試みたが，適合度等を踏まえ採択しなかった。

22）GFI（Goodness of Fit Index）は，0から 1 までの值をとる。1に近いほど啇合度が 高く, .9 以上であることが適合がよいと判断する 1 つ目安とされている。観測変 数が増えると值が小さくなる傾向がある(閌2の各項目は，すべて観浿変数)。 CFI（Comparative of Fit Index）は，GFI で生じる自由度の影響を排除した指標 で, 適合度の目安はGFI と同様である。RMSEA（Root Mean Square Error of Approximation）は，0に近いほどモデルの適合度が高く，.05 より小さい場合はよ い適合とされ，.1より大きい場合は亜い適合とされる。AGFI が本論文のモデルと 同様の，.8以上でモデルを採択している例として，塚田伸也・湯沢昭・森田哲夫・ 西尾敏和 (2016) : 前橋市の大規模公園を事例とした防災機能に関寸る研究: ランド スケープ研究 79 (5), 501-506 等がある。

23）なお, 3. (1) で示した通り, 調査対象となった利用者のうち, 「舟橋村外の持ち 家」が全体の50\%となっていることから，本調䍒結果は，このような舟橋村におけ る定住・転入意向が比較的低いと考えられる㔉性も含んた調査結果となっている。

24）指定管理者である (有) 金岡造園へのヒアリンク調査より。

25）森士一 (2014) : トランスディシプリナリティに関する調査研究 (科学者とステーク ホルダーの超学際協働につい）: 科学コミュニティとステークホルダーの関係性を 考える 第二報告書『文部科学省科学技術・学術政策研究所 DISCUSSION PAPER』No. 105-2. < http://hdl.handle.net/11035/2914> 